\title{
GMR
}

\section{Genetic diversity and relatedness between Canindé and British Alpine goat breeds in Northeastern Brazil accessed by microsatellite markers}

\author{
T.S. Câmara ${ }^{1,2}$, J.F. Nunes ${ }^{2}$, F.M. Diniz ${ }^{3}$, G.R. Silva ${ }^{4}$ and A.M. Araújo ${ }^{5}$ \\ ${ }^{1}$ Programa de Pós-Graduação em Ciências Veterinárias, \\ Universidade Estadual do Ceará, Fortaleza, CE, Brasil \\ ${ }^{2}$ Laboratório de Tecnologia do Sêmen Caprino e Ovino, \\ Universidade Estadual do Ceará, Fortaleza, CE, Brasil \\ ${ }^{3}$ Embrapa Caprinos e Ovinos, Sobral, CE, Brasil \\ ${ }^{4}$ Universidade Federal do Piauí, \\ Campus Universitário Ministro Petrônio Portella, Teresina, PI, Brasil \\ ${ }^{5}$ Embrapa Meio-Norte, Teresina, PI, Brasil \\ Corresponding author: T.S. Câmara \\ E-mail: talitavet2003@gmail.com
}

Genet. Mol. Res. 16 (1): gmr16019569

Received December 8, 2016

Accepted February 20, 2017

Published March 30, 2017

DOI http://dx.doi.org/10.4238/gmr16019569

Copyright $(92017$ The Authors. This is an open-access article distributed under the terms of the Creative Commons Attribution ShareAlike (CC BY-SA) 4.0 License.

\begin{abstract}
The aim of this study was to access the genetic diversity and relatedness between Canindé and British Alpine goat breeds in the States of Piauí and Ceará using microsatellite markers. Genomic DNA was isolated from hair samples of 99 goats belonging to six different flocks. A panel of polymorphic heterologous microsatellite loci was used to genotype individuals. The microsatellite markers resulted in a total number of 145 alleles, with an average of 8.5 alleles per locus. The observed and expected heterozygosities were $\geq 0.687$ and $\geq 0.627$, respectively, for all loci. The polymorphic information content showed that all loci were highly informative with an overall mean of 0.757 .
\end{abstract}

Genetics and Molecular Research 16 (1): gmr16019569 
Overall $F_{\mathrm{ST}}$ across all populations and loci was $18 \%$, which was consistent with the coefficient of gene differentiation $\left(G_{\mathrm{ST}}=0.104\right)$. AMOVA revealed that $12.8 \%$ of the variation was captured between breeds. The Bayesian STRUCTURE clustering detected the maximum likelihood for a model of two genetically distinct groups, in agreement with the number of predefined studied breeds and the two-dimensional plot from the PCoA analysis. The exotic British Alpine breed and the naturalized Brazilian Canindé breed were clearly differentiated by the microsatellite markers, indicating that these two breeds have distant genetic identities, despite the phenotypic similarity.

Key words: Conservation genetics; Genetic differentiation; Naturalized goats; Molecular markers

\section{INTRODUCTION}

Portuguese and Spanish settlers introduced many livestock breeds in Brazil shortly after discovery. These farm animals have been submitted to a long process of natural selection over many generations that produced locally adapted population of goats that showed, for example, high survival capacity associated with a high prolificity, even under the adverse climatic conditions of Northeastern Brazil (McManus et al., 2010).

The major naturalized goat breeds and locally adapted ecotypes raised in the Northeast region are Moxotó, Canindé, Marota, Repartida, Gurguéia, Azul, and Nambi (Lôbo et al., 2010). Among these, the Canindé goat stands out for being one of the two recognized breeds in Brazil, according to the Brazilian Ministry of Agriculture (Santos, 2003). These animals are rustic and well adapted to harsh environment, show desirable traits such as disease resistance and fecundity and a significant potential for milk production (McManus et al., 2010). Therefore, naturalized goats play an important socio-economic role for the low-income population with a strong rural background in the Northeast region. This Brazilian region, currently concentrate $90.3 \%$ of the national caprine herd (IBGE, 2012).

Undesigned crossbreeding involving exotic breeds or even other naturalized breed is threatening the goat genetic diversity and, consequentially, leading to the Brazilian local breed extinction (Araújo et al., 2006). As a result, the conservation of naturalized breeds and locally adapted ecotypes has been defended not only because of the important genetic variability of these animals, but also due to its contribution to rural development, especially for smallholder goat farmers (Lôbo et al., 2010). Therefore, a considerable effort focused on conservation studies is being devoted to these animals (Ribeiro et al., 2004; Menezes et al., 2006; Rocha et al., 2016).

In this context, molecular markers are essential as a tool in conservation and genetic improvement programs, assisting in the estimation of genetic distances between populations and among individuals and in the genetic diversity and relatedness analysis within and between naturalized, exotic purebreds, and crossbred goats (Dixit et al., 2012).

Due to the great phenotypic similarity, it is hypothesized that British Alpines have given rise to Canindé goats (Nunes et al., 1997). Despite to their importance within rural smallholder farming systems in the Northeast region, little is still known about the genetic relationships between these two breeds, and therefore, the objective of this study was to determine the genetic diversity and relatedness between herds of Canindé and British Alpine

Genetics and Molecular Research 16 (1): gmr16019569 
goats in the States of Piauí and Ceará using heterologous microsatellite loci. The results from this study would also provide valuable information for the Ministry of Agriculture, in the sense that additional knowledge support will be added to the phenotypic survey previously conducted (Santos, 2003) for recognition of Canindé goats as a naturalized breed.

\section{MATERIAL AND METHODS}

\section{Sampling and DNA extraction}

A total of 99 goats were randomly sampled from two different breeds: British Alpine $(\mathrm{N}=46)$ and Canindé $(\mathrm{N}=53)$ (Figure 1). Animals were collected from farms located in the Brazilian Northeast region in the States of Piauí and Ceará (Figure 2 and Table 1). Ethical approval (No. 6305558/2014) for the study was obtained from the Ethics Committee for Animal Research of the Federal University of Ceará, Brazil.

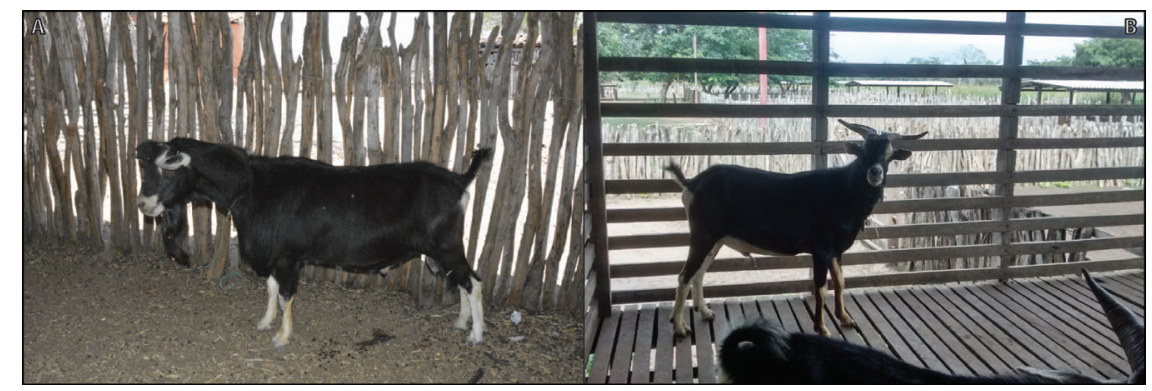

Figure 1. Representative animals of the British Alpine (left) and Canindé (right) breeds (from personal photo collection).

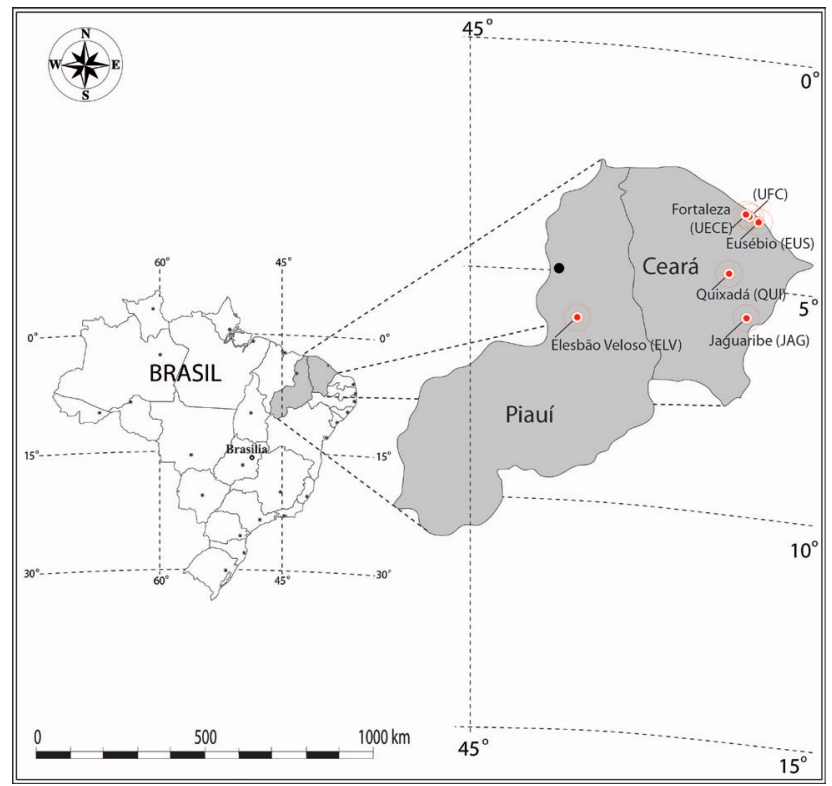

Figure 2. Map of sampling sites for goat breeds in Brazil.

Genetics and Molecular Research 16 (1): gmr16019569 
Table 1. List of the goat populations studied with total number of individuals collected in parentheses and their respective location coordinates.

\begin{tabular}{l|l|l|l|c}
\hline Breed (N) & Brazilian state & City (Code) & Geographic location & Number of genotypes \\
\hline \multirow{3}{*}{ Canindé (53) } & Ceará & Fortaleza (UECE) & $3^{\circ} 78^{\prime} 56^{\prime \prime} \mathrm{S} ; 38^{\circ} 55^{\prime} 33^{\prime \prime} \mathrm{W}$ & 3 \\
\cline { 2 - 5 } & Ceará & Fortaleza (UFC) & $3^{\circ} 75^{\prime} 49^{\prime \prime} \mathrm{S} ; 38^{\circ} 55^{\prime} 54^{\prime \prime} \mathrm{W}$ & 8 \\
\cline { 2 - 5 } & Piaú & Elesbão Veloso (ELV) & $6^{\circ} 24^{\prime} 44^{\prime \prime} \mathrm{S} ; 42^{\circ} 15^{\prime} 27^{\prime \prime} \mathrm{W}$ & 42 \\
\hline \multirow{2}{*}{ Alpina Britânica (46) } & Ceará & Eusébio (EUS) & $3^{\circ} 89^{\prime} 88^{\prime \prime} \mathrm{S} ; 38^{\circ} 45^{\prime} 21^{\prime \prime} \mathrm{W}$ & 9 \\
\cline { 2 - 5 } & Ceará & Quixadá (QUI) & $4^{\circ} 96^{\prime} 43^{\prime \prime} \mathrm{S} ; 39^{\circ} 01^{\prime} 12^{\prime \prime} \mathrm{W}$ & 20 \\
\cline { 2 - 5 } & Ceará & Jaguaribe (JAG) & $5^{\circ} 89^{\prime} 72^{\prime \prime} \mathrm{S} ; 38^{\circ} 62^{\prime} 98^{\prime \prime} \mathrm{W}$ & 17 \\
\hline
\end{tabular}

Genomic DNA was extracted from hair bulbs (10-15) following the standard HotSHOT protocol as described by Truett et al. (2000). Alkaline lysis buffer was heated to $95^{\circ} \mathrm{C}$ for 20 min; then, samples were cooled to $4^{\circ} \mathrm{C}$ and $\mathrm{pH}$ adjusted to 5 with $40 \mathrm{mM}$ Tris-HCl. DNA was quantified using a NanoDrop 1000 Spectrophotometer (Thermo Scientific) and quality was checked using electrophoresis on $1 \%$ agarose gels.

\section{Microsatellite genotyping}

A set of 20 microsatellite loci (Table 2) was selected based on the guidelines of ISAG/FAO's Domestic Animal Diversity Information System - Measurement of Domestic Animal diversity (DADIS-MoDAD) programmed to generate genotype data of 99 animals. Microsatellite loci were amplified via polymerase chain reaction (PCR), which was carried out in about $25 \mathrm{ng}$ genomic DNA in a $10-\mu \mathrm{L}$ reaction volume. The reaction mixture consisted of 1.85-3.0 $\mathrm{mM} \mathrm{MgCl}_{2}, 0.8 \mathrm{mM}$ dNTPs, $0.5 \mu \mathrm{M}$ (each primer) and $1 \mathrm{U}$ Taq DNA polymerase. All amplifications were run in a Veriti 96-well Thermal Cycler (Applied Biosystems) using the PCR temperature profile indicated in Table 2. The amplification products were screened by silver nitrate detection on denatured $6 \%$ polyacrylamide gels. A 10-bp ladder (Invitrogen) was used as a size standard for sizing PCR products.

\section{Statistical analysis}

The genotype data were initially analyzed using Micro-Checker v. 2.2.3 (Van Oosterhout et al., 2004) to test for the presence of null alleles, large allele dropout, and scoring errors by stuttering. Observed and expected heterozygosities $\left(H_{\mathrm{O}}\right.$ and $\left.H_{\mathrm{E}}\right)$ and the polymorphic information content (PIC) were determined using Cervus v. 3.0.3 (Marshall et al., 1998). Allelic richness $\left(A_{\mathrm{R}}\right)$ was calculated by Fstat v. 2.9.3.2 (Goudet, 2002). Deviations from Hardy-Weinberg equilibrium (HWE) and tests for linkage disequilibrium were conducted using the GENEPOP web-based software v.4.0.10 (Raymond and Rousset, 1995). Sequential Bonferroni adjustments were applied when multiple-pairwise tests were performed to assess statistical significance $(\mathrm{P}<0.05)$.

Fixation indices were estimated using GenAlEx v. 6.5 (Peakall and Smouse, 2012) and ARLEQUin v.3.5.2.2 (Schneider et al., 2000). Analysis of molecular variance (AMOVA) was performed using ARLEQUIN at two hierarchical levels of structure including all populations as a single group, at first, and then grouping populations according to the belonging breeds. Confidence intervals for fixation indices were generated by bootstrapping over loci (20,000 replicates).

Genetics and Molecular Research 16 (1): gmr16019569 
Table 2. Markers and chromosome (chr.) location, primer sequence, experimental parameters used for the amplification of 20 microsatellite loci, allele size range (bp) detected, and their GenBank accession number.

\begin{tabular}{|c|c|c|c|c|c|c|c|}
\hline Locus & \begin{tabular}{|l|} 
Chr. location \\
\end{tabular} & \begin{tabular}{|l|l} 
Primer sequence $\left(5^{\prime}-3^{\prime}\right)$ \\
\end{tabular} & $\mathrm{MgCl}_{2}(\mathrm{mM})$ & \begin{tabular}{|l|} 
Buffer $(10 \mathrm{X})$ \\
\end{tabular} & \begin{tabular}{|l} 
PCR profile \\
\end{tabular} & $\begin{array}{l}\text { Allele size } \\
\text { range (bp) }\end{array}$ & $\begin{array}{c}\text { GenBank } \\
\text { accession No. }\end{array}$ \\
\hline${ }^{*}$ ILSTS087 & BTA6 & $\begin{array}{l}\text { F: CTGCCTCTTTTCTTGAGAGC } \\
\text { R: AGGAATATCTGTATCAACCGCAGTC }\end{array}$ & 1.875 & 1.25 & $\begin{array}{l}94^{\circ} \mathrm{C}-3^{\prime} ; 35 \mathrm{X}\left(94^{\circ} \mathrm{C}-40^{\prime \prime} ; 55^{\circ} \mathrm{C}-40^{\prime \prime} ; 72^{\circ} \mathrm{C}-40^{\prime \prime}\right) ; \\
72^{\circ} \mathrm{C}-7^{\prime} ; 12^{\circ} \mathrm{C}\end{array}$ & $135-153$ & L37279 \\
\hline INRA $172^{a}$ & BTA26 & $\begin{array}{l}\text { F: CCACTTCCCTGTATCCTCCT } \\
\text { R: GGTGCTCCCATTGTGTAGAC }\end{array}$ & 1.875 & 1.25 & $\begin{array}{l}94^{\circ} \mathrm{C}-3^{\prime} ; 35 \mathrm{X}\left(94^{\circ} \mathrm{C}-40^{\prime \prime} ; 55^{\circ} \mathrm{C}-40^{\prime \prime} ; 72^{\circ} \mathrm{C}-40^{\prime \prime}\right) ; \\
72^{\circ} \mathrm{C}-7^{\prime} ; 12^{\circ} \mathrm{C}\end{array}$ & $136-152$ & $\mathrm{X} 74205$ \\
\hline OarFcb48 & OAR17 & $\begin{array}{l}\text { F: GAGTTAGTACAAGGATGACAAGAGGCAC } \\
\text { R: GACTCTAGAGGATCGCAAAGACCAG }\end{array}$ & 1.875 & 1.25 & $\begin{array}{l}94^{\circ} \mathrm{C}-33^{\prime} ; 35\left(94^{\circ} \mathrm{C}-40^{\prime \prime} ; 55^{\circ} \mathrm{C}-40^{\prime \prime} ; 72^{\circ} \mathrm{C}-40^{\prime \prime}\right) ; \\
72^{\circ} \mathrm{C}-7^{\prime} ; 12^{\circ} \mathrm{C}\end{array}$ & $152-164$ & M82875 \\
\hline INRA35 $^{\circ}$ & 16 & $\begin{array}{l}\text { F: TTGTGCTTTATGACACTATCCG } \\
\text { R: ATCCTTTGCAGCCTCCACATTG }\end{array}$ & 2.0 & 1.25 & $\begin{array}{l}94^{\circ} \mathrm{C}-3^{\prime} ; 30 \mathrm{X}\left(94^{\circ} \mathrm{C}-40^{\prime \prime} ; 46^{\circ} \mathrm{C}-40^{\prime \prime} ; 72^{\circ} \mathrm{C}-40^{\prime \prime}\right) ; \\
72^{\circ} \mathrm{C}-7^{\circ} ; 2^{\circ} \mathrm{C}\end{array}$ & $100-124$ & X68049 \\
\hline INRA005 $^{\circ}$ & 12 & $\begin{array}{l}\text { F: CAATCTGCATGAAGTATAAATAT } \\
\text { R: CTTCAGGCATACCCTACACC }\end{array}$ & 2.0 & 1.25 & $\begin{array}{l}94^{\circ} \mathrm{C}-3 ; ; 30 \mathrm{X}\left(94^{\circ} \mathrm{C}-40^{\prime \prime} ; 46^{\circ} \mathrm{C}-40^{\prime \prime} ; 72^{\circ} \mathrm{C}-40^{\prime \prime}\right) ; \\
72^{\circ} \mathrm{C}-7^{\prime} ; 12^{\circ}{ }^{\circ} \mathrm{c}\end{array}$ & $125-155$ & $\mathrm{X} 63793$ \\
\hline${\text { HAUT } 27^{\circ}}^{\circ}$ & 26 & $\begin{array}{l}\text { F: AACTGCTGAAATCTCCATCTTA } \\
\text { R: TTTTATGTTCATTTTTTGACTGG }\end{array}$ & 2.0 & 1.25 & $\begin{array}{l}94^{\circ} \mathrm{C}-33^{\prime} ; 30 \mathrm{X}\left(94^{\circ} \mathrm{C}-40^{\prime \prime} ; 40^{\circ} \mathrm{C}-40^{\prime \prime} ; 72^{\circ} \mathrm{C}-40^{\prime \prime}\right) \\
72^{\circ} \mathrm{C}-7^{\prime} ; 12^{\circ}{ }^{\circ} \mathrm{C}\end{array}$ & $125-160$ & $\mathrm{X} 89252$ \\
\hline INRA023 & 3 & $\begin{array}{l}\text { F: GAGTAGAGCTACAAGATAAACTTC } \\
\text { R: TAACTACAGGGTGTTAGATGAACTC }\end{array}$ & 1.875 & 1.25 & $\begin{array}{l}94^{\circ} \mathrm{C}-33^{\prime} ; 35 \mathrm{X}\left(94^{\circ} \mathrm{C}-40^{\prime \prime} ; 55^{\circ} \mathrm{C}-40^{\prime \prime} ; 72^{\circ} \mathrm{C}-40^{\prime \prime}\right) \\
72^{\circ} \mathrm{C}-7 ; 12^{\circ} \mathrm{C}\end{array}$ & $197-215$ & $\mathrm{X} 67830$ \\
\hline${ }^{*}$ ILSTS01 $1^{a}$ & OAR 9 & $\begin{array}{l}\text { F: GCTTGCTACATGGAAAGTGC } \\
\text { R: CTAAAATGCAGAGCCCTACC }\end{array}$ & 1.875 & 1.25 & $\begin{array}{l}94^{\circ} \mathrm{C}-3^{\prime} ; 35 \mathrm{X}\left(94^{\circ}-40^{\prime \prime} ; 55^{\circ} \mathrm{C}-40^{\prime \prime} ; 72^{\circ} \mathrm{C}-40^{\prime \prime}\right) \\
72^{\circ} \mathrm{C}-7^{\prime} ; 12^{\circ} \mathrm{C}\end{array}$ & $262-280$ & L23485 \\
\hline $\mathrm{ILSTSO}_{19^{\circ}}$ & Ann & $\begin{array}{l}\text { F: AAGGGACCTCATGTAGAAGC } \\
\text { R: ACTTTTGGACCCTGTAGTGC }\end{array}$ & 2.0 & 1.25 & $\begin{array}{l}94^{\circ} \mathrm{C}-3^{\prime} ; 30 \mathrm{X}\left(94^{\circ} \mathrm{C}-40^{\prime \prime} ; 46^{\circ} \mathrm{C}-40^{\prime \prime} ; 72^{\circ} \mathrm{C}-40^{\prime \prime}\right) ; \\
72^{\circ} \mathrm{C}-7 ; 12^{\circ} \mathrm{C}\end{array}$ & $144-156$ & L23492 \\
\hline ETH225 & 9 & $\begin{array}{l}\text { F: GATCACCTTGCCACTATTTCCT } \\
\text { R: ACATGACAGCCAGCTGCTACT }\end{array}$ & 3.0 & 1.25 & $\begin{array}{l}94^{\circ} \mathrm{C}-3^{\prime} ; 40 \mathrm{X}\left(94^{\circ} \mathrm{C}-40^{\prime \prime} ; 48^{\circ} \mathrm{C}-40^{\prime \prime} ; 72^{\circ} \mathrm{C}-40^{\prime \prime}\right) \\
72^{\circ} \mathrm{C}-7 ; 12^{\circ} \mathrm{C}\end{array}$ & $135-250$ & Z14043 \\
\hline INRA63 $^{\mathrm{a}}$ & 18 & $\begin{array}{l}\text { F: ATTTGCACAAGCTAAATCTAACC } \\
\text { R: AAACCACAGAAATGCTTGGAAG }\end{array}$ & 2.0 & 1.25 & $\begin{array}{l}94^{\circ} \mathrm{C}-3^{\prime} ; 30 \mathrm{X}\left(94^{\circ} \mathrm{C}-40^{\prime \prime} ; 50^{\circ} \mathrm{C}-40^{\prime \prime} ; 72^{\circ} \mathrm{C}-40^{\prime \prime}\right) ; \\
72^{\circ} \mathrm{C}-7 ; 112^{\circ} \mathrm{C}\end{array}$ & $153-185$ & $\mathrm{X} 71507$ \\
\hline $\mathrm{HEL}^{c}$ & 8 & $\begin{array}{l}\text { F: CCCATTCAGTCTTCAGAGGT } \\
\text { R: CACATCCATGTTCTCACCAC }\end{array}$ & 3.0 & 1.25 & $\begin{array}{l}95^{\circ} \mathrm{C}-15^{\prime} ; 40 \mathrm{X}\left(94^{\circ} \mathrm{C}-40^{\prime \prime} ; 46^{\circ} \mathrm{C}-40^{\prime \prime} ; 72^{\circ} \mathrm{C}-40^{\prime}\right) \\
72^{\circ} \mathrm{C}-7^{\prime} ; 12^{\circ} \mathrm{C}\end{array}$ & $90-110$ & $\mathrm{X} 65214$ \\
\hline $\mathrm{CSRM}^{\circ} 0^{\mathrm{C}}$ & 10 & $\begin{array}{l}\text { F: AAGATGTGATCCAAGAGAGAGGCA } \\
\text { R: AGGACCAGATCGTGAAAGGCATAG }\end{array}$ & 2.0 & 2.0 & $\begin{array}{l}94^{\circ} \mathrm{C}-5^{\circ} ; 10 \mathrm{X}\left(94^{\circ} \mathrm{C}-40^{\circ \prime} ; 56^{\circ} \mathrm{C}\left[-1.0^{\circ} \mathrm{C} / \mathrm{cycle}-40^{\prime \prime} ; 72^{\circ} \mathrm{C}-40^{\prime \prime}\right) ;\right. \\
30 \mathrm{X}\left(94^{\circ} \mathrm{C}-40^{\circ \prime} ; 46^{\circ} \mathrm{C}-40^{\circ} ; 72^{\circ} \mathrm{C}-40^{\prime \prime} ; 72^{\circ} \mathrm{C}-7 ; ; 12^{\circ} \mathrm{C}\right.\end{array}$ & $75-110$ & AF232758 \\
\hline ILSTS005 ${ }^{\mathrm{a}}$ & 10 & $\begin{array}{l}\text { F: GGAAGCAAATGAAATCTAATAGCC } \\
\text { R: TGTTCTGTGAGTTTGTAAGC }\end{array}$ & 2.0 & 1.25 & 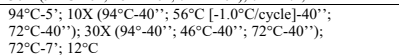 & 176-194 & L23481 \\
\hline${ }^{*} \mathrm{BM} 1824^{\mathrm{b}}$ & 1 & $\begin{array}{l}\text { F: GAGCAAGGTGTTTTTCCAATC } \\
\text { R: CATTCTCCAACTGCTTCCTTG }\end{array}$ & 2.0 & 1.25 & $\begin{array}{l}94^{\circ} \mathrm{C}-5^{\prime} ; 10 \mathrm{X}\left(94^{\circ} \mathrm{C}-40^{\prime \prime} ; 56^{\circ} \mathrm{C}\left[-1.0^{\circ} \mathrm{C} / \text { cycle] }-40^{\prime \prime} ; 72^{\circ} \mathrm{C}-{ }^{\circ}\right.\right. \\
\left.40^{\prime \prime}\right) ; 30 \mathrm{C}\left(94^{\circ} \mathrm{C}-40^{\prime \prime} ; 46^{\circ} \mathrm{C}-40^{\prime \prime} ; 72^{\circ} \mathrm{C}-40^{\prime \prime}\right) ; 72^{\circ} \mathrm{C}-7^{\prime} ; 12^{\circ} \mathrm{P}\end{array}$ & $170-218$ & G18394 \\
\hline ILSTS030 $0^{d}$ & 2 & $\begin{array}{l}\text { F: CTGCAGTTCTGCATATGTGG } \\
\text { R: CTTAGACAACAGGGTTTGG }\end{array}$ & 1.5 & 1.25 & $\begin{array}{l}94^{\circ} \mathrm{C}-5^{\prime} ; 10 \mathrm{X}\left(94^{\circ} \mathrm{C}-40^{\prime \prime} ; 59^{\circ} \mathrm{C}\left[-1.0^{\circ} \mathrm{C} / \text { cycle] }-40^{\circ \prime} ; 70^{\circ} \mathrm{C}-{ }^{\circ}\right.\right. \\
\left.40^{\prime \prime}\right) ; 40 \mathrm{C}\left(94^{\circ} \mathrm{C}-40^{\prime \prime} ; 49^{\circ} \mathrm{C}-40^{\prime \prime} ; 72^{\circ} \mathrm{C}-40^{\prime \prime}\right) ; 72^{\circ} \mathrm{C}-7^{\prime} ; 12^{\circ} \mathrm{P}\end{array}$ & $146-158$ & L37212 \\
\hline ILSTS006 & 7 & $\begin{array}{l}\text { F: TGTCTGTATTTCTGCTGTGG } \\
\text { R: ACACGGAAGCGATCTAAACG }\end{array}$ & 3.0 & 1.25 & 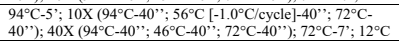 & $277-309$ & L23482 \\
\hline ETH $10^{2}$ & 5 & $\begin{array}{l}\text { F: GTTCAGGACTGGCCCTGCTAACA } \\
\text { R: CCTCCAGCCCACTTTCTCTTCTC }\end{array}$ & 3.0 & 2.0 & 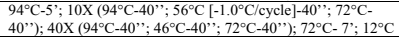 & $200-230$ & Z22739 \\
\hline INRA006 ${ }^{c}$ & $\mathrm{CH} 3$ & $\begin{array}{l}\text { F: TGAGCTGGGGTGGGAGCTATAAATA } \\
\text { R: AGGAATATCTGTATCAACCGCAGTC }\end{array}$ & 3.0 & 1.25 & $\begin{array}{l}94^{\circ} \mathrm{C}-3^{\circ} ; 40 \mathrm{X}\left(94^{\circ} \mathrm{C}-40^{\prime \prime} ; 46^{\circ} \mathrm{C}-40^{\prime \prime} ; 72^{\circ} \mathrm{C}-40^{\circ}\right) \\
72^{\circ} \mathrm{C}-7^{\prime} ; 12^{\circ} \mathrm{C}\end{array}$ & $87-120$ & $\mathrm{X} 637951$ \\
\hline ETH185 & 17 & $\begin{array}{l}\text { F: TGCATGGACAGAGCAGCCTGGC } \\
\text { R: GCACCCCAACGAAAGCTCCCAG }\end{array}$ & 2.0 & 2.0 & 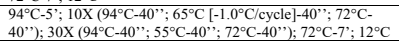 & $110-130$ & Z14042 \\
\hline
\end{tabular}

${ }^{a}$ Microsatellite locus markers developed for caprine; ${ }^{b}$ ovine; ${ }^{c}$ bovine; dbubaline. *Microsatellite primers were optimized and are also listed, but excluded from subsequent analyses.

A Bayesian clustering analysis, admixture model, was performed to infer possible differentiation between goat breeds using the Structure v.2.3.4 software (Pritchard et al., 2000). The program was set up for 1,000,000 Markov chain Monte Carlo repetitions after an initial burn-in of 500,000 steps. The estimate of the best $\mathrm{K}$ was calculated based on 10 replications for each K (from 1 to 6) as described by Evanno et al. (2005) using Structure Harvester v.0.6.1 (Earl and VonHoldt, 2012). The ClumpP v.1.1.2 program (Jakobsson and Rosenberg, 2007) was used to align the 10 repetitions of the best K. The Distruct v.1.1 program (Noah, 2004) was applied to graphically display the results produced by CuumPP. The genetic relationship between breeds and populations was also analyzed using principal coordinate analysis (PCoA) and a genetic distance matrix using GENALEx.

The genetic relationship between Canindé and British Alpine goat breeds and among populations was also investigated by an unweighted pair-group method using arithmetic averages (UPGMA) of Nei's genetic distance. The PAST v.3.11 software (Hammer et al., 2001) was used to construct the tree based on the genetic relationships generated in the distance matrix. To examine the confidence level of nodes (topology tree) derived from the phylogenetic analysis, 1000 bootstrap replications of the original set of data were performed.

\section{RESULTS}

\section{Genetic diversity and polymorphism among loci}

All twenty pairs of microsatellite primers amplified consistent and well-defined 
bands across all populations. Three loci (ILSTS011, ILSTS087, and BM1824) showed strong evidence of null alleles with frequencies of $0.227,0.110$. and 0.323 , respectively, and therefore, excluded from further analysis (Table 3 ).

Table 3. Sample size $(\mathrm{N})$, number of alleles per locus $\left(N_{\mathrm{A}}\right)$, allelic richness $\left(A_{\mathrm{R}}\right)$, observed $\left(H_{\mathrm{O}}\right)$ and expected heterozygosities $\left(H_{\mathrm{E}}\right)$, polymorphic information content $(\mathrm{PIC})$, within population fixation index $\left(F_{\mathrm{IS}}\right)$, total fixation index $\left(F_{\text {IT }}\right)$, genetic divergence among populations $\left(F_{\mathrm{ST}}\right)$, and its analogue $G_{\mathrm{ST}}($ Nei, 1973) obtained for each individual locus.

\begin{tabular}{l|c|c|c|c|c|c|c|c|c|c}
\hline Locus* & $\mathrm{N}$ & $N_{\mathrm{A}}$ & $A_{\mathrm{R}}$ & $H_{\mathrm{O}}$ & $H_{\mathrm{E}}$ & PIC & $F_{\text {IS }}$ & $F_{\text {IT }}$ & $F_{\mathrm{ST}}$ & $G_{\mathrm{ST}}$ \\
\hline ILSTS019 & 82 & 8 & 6.9 & 1.000 & 0.769 & 0.734 & -0.323 & -0.284 & 0.029 & 0.015 \\
\hline Oarf48 & 73 & 10 & 9.0 & 0.918 & 0.844 & 0.820 & -0.167 & -0.019 & 0.126 & 0.068 \\
\hline INRAbern172 & 75 & 11 & 10.6 & 1.000 & 0.874 & 0.856 & -0.228 & -0.072 & 0.127 & 0.068 \\
\hline ILSTS005 & 74 & 5 & 4.7 & 0.838 & 0.627 & 0.553 & -0.387 & -0.294 & 0.067 & 0.035 \\
\hline CSRM60 & 89 & 9 & 8.7 & 0.798 & 0.870 & 0.850 & 0.018 & 0.139 & 0.123 & 0.066 \\
\hline ILSTS030 & 87 & 11 & 9.1 & 0.897 & 0.769 & 0.734 & -0.352 & -0.027 & 0.240 & 0.133 \\
\hline ETH225 & 94 & 9 & 8.4 & 1.000 & 0.829 & 0.803 & -0.318 & -0.115 & 0.154 & 0.084 \\
\hline HEL9 & 68 & 9 & 7.4 & 1.000 & 0.828 & 0.798 & -0.354 & -0.093 & 0.192 & 0.107 \\
\hline ILSTS006 & 82 & 6 & 5.5 & 0.793 & 0.768 & 0.728 & -0.413 & 0.056 & 0.175 & 0.096 \\
\hline INRA005 & 72 & 12 & 11.0 & 1.000 & 0.880 & 0.861 & -0.200 & -0.073 & 0.105 & 0.057 \\
\hline INRA006 & 81 & 13 & 10.1 & 0.901 & 0.844 & 0.821 & -0.134 & -0.010 & 0.109 & 0.058 \\
\hline INRA23 & 67 & 6 & 4.9 & 0.687 & 0.698 & 0.631 & -0.510 & 0.279 & 0.523 & 0.364 \\
\hline INRA35 & 80 & 9 & 8.7 & 1.000 & 0.833 & 0.808 & -0.324 & -0.110 & 0.169 & 0.094 \\
\hline INRA63 & 64 & 8 & 6.7 & 0.984 & 0.775 & 0.736 & -0.304 & -0.241 & 0.048 & 0.025 \\
\hline ETH10 & 83 & 7 & 5.4 & 1.000 & 0.771 & 0.726 & -0.871 & 0.000 & 0.465 & 0.304 \\
\hline HAUT27 & 73 & 8 & 7.7 & 0.822 & 0.840 & 0.813 & -0.035 & 0.071 & 0.103 & 0.055 \\
\hline ETH185 & 96 & 4 & 4.0 & 1.000 & 0.653 & 0.595 & -0.805 & -0.337 & 0.259 & 0.148 \\
\hline Total/mean & - & 8.5 & 7.6 & 0.920 & 0.785 & 0.757 & -0.320 & -0.066 & 0.180 & 0.104 \\
\hline
\end{tabular}

*All loci showed evidence of departure from Hardy-Weinberg equilibrium after sequential Bonferroni adjustment.

The microsatellite panel resulted in a total number of 145 alleles, with an average of 8.5 alleles per locus. The most polymorphic loci were INRA006 (13), INRA005 (12), ILSTS030 (11), INRAbern172 (11), and ETH10 (4) was the least polymorphic locus. Allelic richness, a measure of genetic diversity that takes account of sample size, was in the range of 4 (ETH185) to 11 (INRA005), with an average for each locus of 7.6.

The $H_{\mathrm{O}}$ and $H_{\mathrm{E}}$, commonly used measures of genetic diversity at a single locus, were $>0.687$ and $>0.627$, respectively, for all markers. The average $H_{\mathrm{O}}(0.920)$ was higher than the $H_{\mathrm{E}}(0.785)$, indicating an excess in heterozygosity.

$H_{\mathrm{E}}$ was highest for INRA005 $(0.880)$, which was in accordance with the results for allelic richness (11) and PIC (0.861). Least $H_{\mathrm{E}}$ was shown by ILSTS005 (0.627), which showed the least PIC value (0.553) also. All loci showed statistically significant deviations from HWE.

The PIC showed that all loci were highly informative (PIC > 0.500) indicating the high level of polymorphism across the loci with an overall mean of 0.757 . The Wright's fixation index $\left(F_{\text {IS }}\right)$ was negative for all markers across populations, except CSRM60 that showed a value close to zero (0.018). $F_{\text {IS }}$ varied from - 0.035 (HAUT27) to -0.871 (ETH10). This result corroborates the higher $H_{\mathrm{O}}$ levels $\left(H_{\mathrm{O}}>H_{\mathrm{E}}\right)$ across most loci. $F_{\text {IT }}$ was also negative for 12 of 17 loci with an average of -0.066 .

The genetic differentiation statistics for each locus ranged from 0.029 to 0.523 for $F_{\mathrm{ST}}$ and from 0.015 to 0.364 for $G_{\mathrm{ST}}$. Overall $F_{\mathrm{ST}}$ across all populations and loci was $18 \%$, which was consistent with the coefficient of gene differentiation $\left(G_{\mathrm{ST}}=0.104\right)$, both showing pronounced differentiation among populations (Table 3).

\section{Genetic diversity between breeds}

When genetic diversity parameters were compared between individual breeds

Genetics and Molecular Research 16 (1): gmr16019569 
separately (Table 4), the lowest means for number of alleles and for allelic richness were found in British Alpine, 5.5 and 5.4, respectively. A total of 94 alleles were obtained for British Alpine and 105 alleles for Canindé. Alleles varied from 2 to 10 in British Alpine and in Canindé breeds.

Table 4. Sample size $(\mathrm{N})$, number of alleles per locus $\left(N_{\mathrm{A}}\right)$, allelic richness $\left(A_{\mathrm{R}}\right)$, observed $\left(H_{\mathrm{O}}\right)$ and expected heterozygosities $\left(H_{\mathrm{E}}\right)$, within population fixation index $\left(F_{\mathrm{IS}}\right)$ and polymorphic information content (PIC) obtained for each individual locus for breeds separately.

\begin{tabular}{|c|c|c|c|c|c|c|c|c|c|c|c|c|c|c|}
\hline \multirow[t]{2}{*}{ Locus* } & \multicolumn{7}{|c|}{ British Alpine } & \multicolumn{7}{|c|}{ Canindé } \\
\hline & $\mathrm{N}$ & $N_{\mathrm{A}}$ & $A_{\mathrm{R}}$ & $H_{\mathrm{O}}$ & $H_{\mathrm{E}}$ & $F_{\text {IS }}$ & PIC & $\mathrm{N}$ & $N_{\mathrm{A}}$ & $A_{\mathrm{R}}$ & $H_{\mathrm{O}}$ & $H_{\mathrm{E}}$ & $F_{\text {IS }}$ & PIC \\
\hline ILSTS019 & 41 & 8 & 7.6 & 1.000 & 0.781 & -0.284 & 0.742 & 41 & 5 & 5.0 & 1.000 & 0.736 & -0.364 & 0.686 \\
\hline Oarf48 & 37 & 6 & 5.9 & 1.000 & 0.756 & -0.329 & 0.707 & 36 & 9 & 8.4 & 0.833 & 0.821 & -0.015 & $0.78 \mathrm{c}$ \\
\hline INRAbern172 & 40 & 6 & 5.9 & 1.000 & 0.780 & -0.287 & 0.736 & 35 & 9 & 8.5 & 1.000 & 0.858 & -0.168 & 0.827 \\
\hline ILSTS005 & 36 & 2 & 2.0 & 1.000 & 0.507 & -1.000 & 0.375 & 38 & 5 & 5.0 & 0.684 & 0.702 & 0.025 & 0.647 \\
\hline CSRM60 & 45 & 7 & 6.9 & 0.867 & 0.809 & -0.071 & 0.774 & 44 & 7 & 6.6 & 0.727 & 0.815 & 0.108 & 0.778 \\
\hline ILSTS030 & 39 & 10 & 9.5 & 0.769 & 0.864 & 0.110 & 0.836 & 48 & 2 & 2.0 & 1.000 & 0.505 & -1.000 & 0.37 \\
\hline ETH225 & 44 & 5 & 4.9 & 1.000 & 0.716 & -0.404 & 0.657 & 50 & 7 & 6.9 & 1.000 & 0.801 & -0.251 & 0.76 \\
\hline HEL9 & 31 & 5 & 4.6 & 1.000 & 0.684 & -0.473 & 0.607 & 37 & 7 & 6.4 & 1.000 & 0.791 & -0.269 & 0.74 \\
\hline ILSTS006 & 42 & 5 & 4.8 & 0.738 & 0.751 & 0.017 & 0.696 & 40 & 5 & 4.6 & 0.850 & 0.635 & $\begin{array}{l}-0.20344 \\
-0.344\end{array}$ & 0.560 \\
\hline INRA005 & 26 & 6 & 6.0 & 1.000 & 0.765 & -0.315 & 0.708 & 46 & 10 & 9.8 & 1.000 & 0.875 & -0.144 & 0.851 \\
\hline INRA006 & 38 & 7 & 6.3 & 1.000 & 0.789 & -0.271 & 0.743 & 43 & 10 & 8.6 & 0.814 & 0.801 & -0.015 & 0.76 \\
\hline INRA23 & $\frac{50}{27}$ & $\frac{1}{5}$ & 4.9 & 0.222 & 0.1333 & 0.0 .336 & 0.1314 & $\frac{45}{40}$ & $\frac{10}{3}$ & 3.0 & $\frac{0.014}{1.000}$ & 0.011 & $\begin{array}{l}-0.015 \\
-0.864\end{array}$ & 0.427 \\
\hline INRA35 & 35 & 3 & 3.0 & 1.000 & 0.611 & -0.652 & 0.523 & 45 & 8 & 8.0 & 1.000 & 0.872 & -0.148 & 0.84 \\
\hline INRA63 & 26 & 7 & 7.0 & 1.000 & 0.750 & -0.342 & 0.693 & 38 & 5 & 5.0 & 0.974 & 0.764 & -0.278 & 0.713 \\
\hline ETH10 & 42 & 3 & 2.9 & 1.000 & 0.550 & -0.837 & 0.439 & 41 & 4 & 3.3 & 1.000 & 0.530 & -0.906 & 0.410 \\
\hline $\begin{array}{l}\text { HAUT27 } \\
\end{array}$ & 36 & 6 & $\begin{array}{l}2.9 \\
5.9\end{array}$ & 0.806 & 0.776 & $\begin{array}{r}-0.037 \\
-0.038\end{array}$ & $\begin{array}{l}0.439 \\
0.733\end{array}$ & $\frac{41}{37}$ & 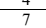 & 6.9 & 0.838 & 0.080 & $\begin{array}{r}-0.000 \\
-0.032\end{array}$ & $\begin{array}{l}0.417 \\
0.77\end{array}$ \\
\hline ETHI 85 & 46 & 3 & 3.0 & 1.000 & 0.617 & $\begin{array}{r}-0.633 \\
\end{array}$ & 0.534 & 50 & 2 & 2.0 & 1.000 & 0.505 & -1.000 & 0.37 \\
\hline Mean & - & 5.5 & 5.4 & 0.906 & 0.696 & -0.322 & 0.636 & - & 6.2 & 5.9 & 0.925 & 0.727 & $\begin{array}{r}-0.333 \\
\end{array}$ & 0.666 \\
\hline
\end{tabular}

*All loci showed evidence of departure from Hardy-Weinberg equilibrium after sequential Bonferroni adjustment.

The mean $H_{\mathrm{O}}$ over the 17 loci was 0.906 for British Alpine and 0.925 for Canindé, which were higher than the mean $H_{\mathrm{E}}\left(0.696\right.$ and 0.727 , respectively) for both breeds. $H_{\mathrm{O}}$ values were higher than 0.700 in 16 of the 17 genotyped loci $(94.11 \%)$, with the exception of ILSTS005 (0.684) for Canindé and INRA023 (0.222) for British Alpine.

For the Canindé goat breed, $H_{\mathrm{O}}$ was larger than $H_{\mathrm{E}}$ in 15 of the 17 loci $(76.47 \%)$, except loci ILSTS005 $(0.684<0.702)$ and CSRM60 $(0.727<0.815)$. For the British Alpine, $H_{\mathrm{O}}$ was higher in 14 loci. $H_{\mathrm{E}}$ was higher in loci ILSTS030 $(0.78<0.864)$, ILSTS006 $(0.738$ $<0.751)$, and INRA023 $(0.222<0.333)$. The $H_{\mathrm{E}}$ was higher than 0.500 for both goat breeds, exception made for Canindé goats in locus INRA023 (0.333). All 17 loci showed significant departures from HWE for the investigated breeds (Table 4).

As expected, PIC values remained as an indicative of the high polymorphic nature of the genotyped microsatellite loci in both breeds, with mean values higher than 0.636 (highly informative).

Within-population inbreeding estimate $F_{\text {IS }}$ was significantly negative in 15 of 17 loci, and mean values were of similar magnitude for British Alpine (-0.322) and Canindé (-0.333), in agreement with the observed excess of heterozygotes.

AMOVA indicated that almost $18.4 \%$ of the variation was accounted for by variation among the populations, while $-23.88 \%$ of the variation was due to among individuals within populations (Table 5). From components of AMOVA across all populations only $F_{\mathrm{ST}}$ was found to be highly significant $(\mathrm{P}<0.01)$. Interspecific variability indicated that $12.8 \%$ of the variation was captured between breeds.

Variability was partitioned among different hierarchical levels. The covariance between breeds $\left(\varphi_{\mathrm{CT}}\right)$ was estimated at 0.128 ( 0.07104 to $0.1927995 \%$ CI over 20.000 bootstrap replications), covariance among populations within breeds $\left(\mathrm{j}_{\mathrm{SC}}\right)$ at $0.11757(0.09228$ to $0.1433395 \% \mathrm{CI})$, and covariance among individuals within populations $\left(\mathrm{j}_{\mathrm{ST}}\right)$ at $-0.370(-0.45746$ to $-0.2932695 \% \mathrm{CI})$. Global estimations for $\varphi_{\mathrm{CT}}$ and $\mathrm{j}_{\mathrm{SC}}$ were statistically significant $(\mathrm{P}<0.05)$.

Genetics and Molecular Research 16 (1): gmr16019569 
Table 5. Global locus-by-locus analysis of molecular variance (AMOVA) as a weighted average over all polymorphic loci.

\begin{tabular}{l|l|c|c|c|l}
\hline Group of samples & Source of variation & SS & VC & Variation (\%) & Fixation index \\
\hline \multirow{2}{*}{ Non-grouped } & Among populations & 110.474 & 1.36160 & 18.37 & $\begin{array}{l}F_{\text {ST }}=0.18374 * \\
(0.11746 \text { to } 0.2696899 \% \mathrm{CI})\end{array}$ \\
\cline { 2 - 6 } & Among individuals within populations & 326.244 & -1.76943 & -23.87716 & $\begin{array}{l}F_{\text {IS }}=-0.29252 \\
(-0.41951 \text { to }-0.1889899 \% \mathrm{CI})\end{array}$ \\
\cline { 2 - 6 } & Within individuals across all populations & 617.500 & 7.81836 & 105.50336 & $\begin{array}{l}F_{\text {IT }}=-0.05503 \\
(-0.13891 \text { to } 0.0323299 \% \mathrm{CI})\end{array}$ \\
\hline Canindé $v s$ British Alpine & Between breeds & 110.474 & 0.95082 & 12.81681 & $\begin{array}{l}F_{\mathrm{CT}}=0.12817 * \\
(0.07104 \text { to } 0.1927995 \% \mathrm{CI})\end{array}$ \\
\cline { 2 - 6 } & Among populations within breeds & 67.684 & 0.76039 & 10.24993 & $\begin{array}{l}F_{\text {ST }}=0.11757 * \\
(0.09228 \text { to } 0.1433395 \% \mathrm{CI})\end{array}$ \\
\cline { 2 - 6 } & Among individuals within populations & 258.560 & -2.11104 & -28.45635 & $\begin{array}{l}F_{\text {SC }}=-0.36988 \\
(-0.45746 \text { to }-0.2932695 \% \mathrm{CI})\end{array}$ \\
\hline
\end{tabular}

$\mathrm{SS}$, sum of squares; $\mathrm{VC}$, variance components; $F_{\mathrm{ST}}$, variance among populations; $F_{\mathrm{ST}}$, fixation index within populations; $F_{\mathrm{SC}}$, fixation index among populations within groups; $F_{\mathrm{CT}}$, fixation index between groups. * Significant at $\mathrm{P}<0.05$ after a random permutation test $(20,000$ permutations).

The ad hoc statistic $\Delta K$, used to infer the true number of clusters (K) that capture the major structure of the dataset, revealed that the best $K$ value was $K=2$, with very strong signal $(\Delta K>1500)$, as seen in Figure 3. Therefore, using the model-based Bayesian clustering analysis, the two breeds could be assigned separately in very distinct clusters and did not share any significant common genetic pattern (Figure 4). AMOVA results provided the highest among population variance component for the two-breed partition in support of the STRUCTURE analysis, although $F_{\text {ST }}$ values differed little among the two-breed grouping tested here (Table 5).

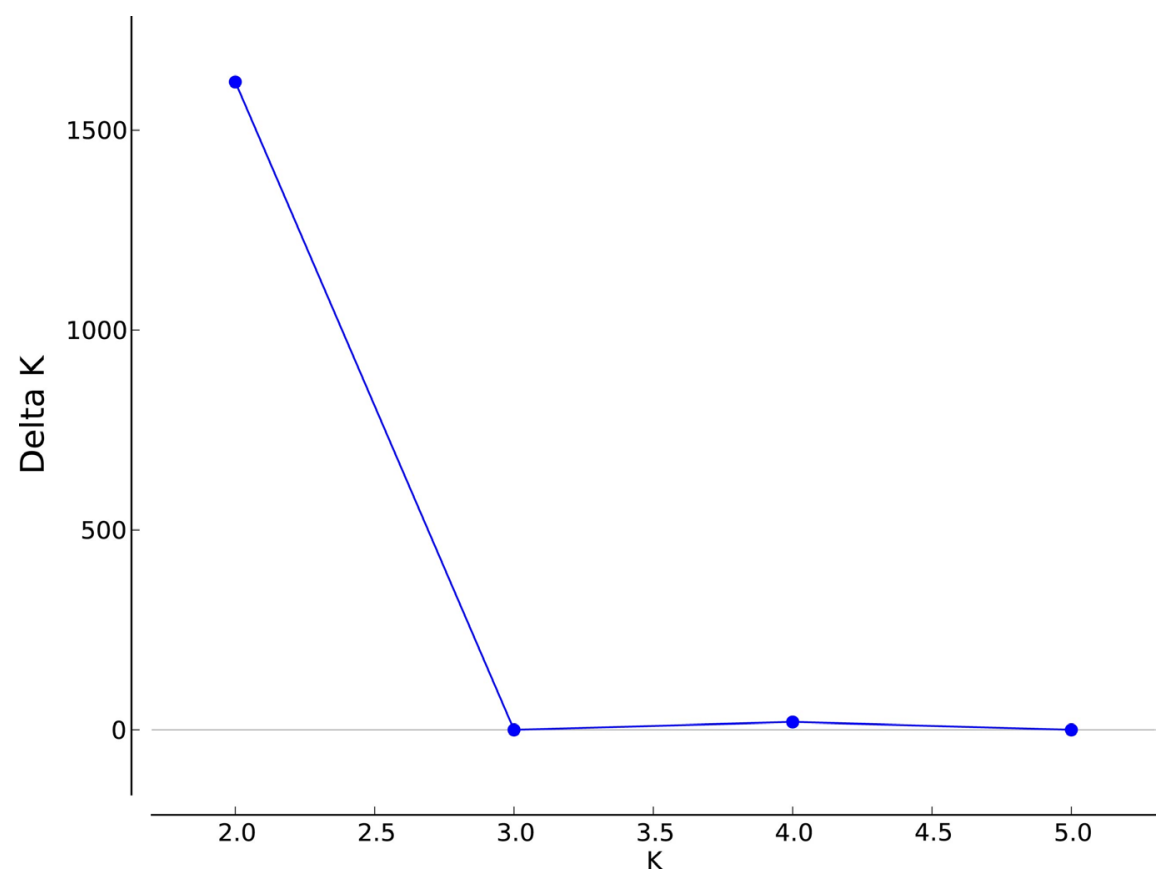

Figure 3. Determination of the best number of clusters from STRUCTURE analysis for microsatellite loci in goat populations.

Genetics and Molecular Research 16 (1): gmr16019569 


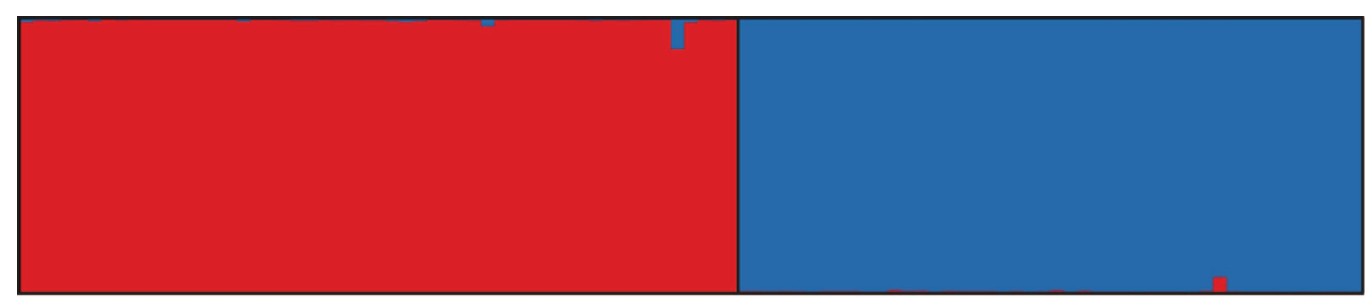

Canindé

British Alpine

Figure 4. Bar plots from inferred population structure using the Bayesian grouping admixture model-based program STRUCTURE $(\mathrm{K}=2)$.

PCoA was also applied using allele frequencies of all the variable loci to represent the individual relationships between populations, as shown in Figure 5. As can be seen, there is a neat separation of the two breeds, and only one outlier, an individual that moved away from the ideal grouping area, was observed for the British Alpine breed. All Canindé goats clustered in a very homogeneous area, forming a tight cluster with no scatter.

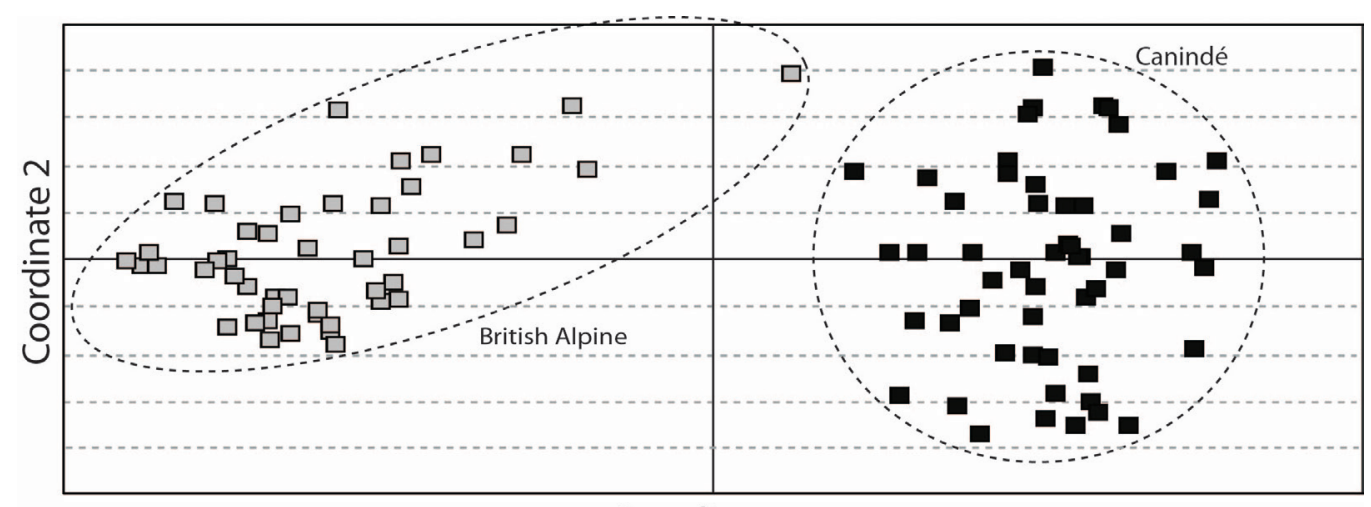

Coordinate 1

Figure 5. Scatter-plot of the principal coordinate analysis $(\mathrm{PCoA})$ based on allele frequency of goat populations. Canindé genotypes (closed squares); British Alpine genotypes (empty squares).

An UPGMA phenogram generated by a matrix of Nei's genetic distances corrected for small populations is presented in Table 6. Distances between populations in the same breed ranged from 0.289 (UFC x UECE) to 0.578 (ELV x UECE) for Canindé and 0.249 (JAG x QUI) to 0.522 (JAG x EUS) for British Alpine. The less divergent population from British Alpine in relation to the Canindé breed (UECE) was that from QUI $\left(D_{C}=0.101\right)$. QUI (British Alpine) and UFC (Canindé) were the most genetically distant populations between these breeds.

The tree from inter-population genetic distance using UPGMA algorithm displayed two well-defined clusters, obtained at a distance of 2.22, for the investigated breeds (Figure 6), which highlights that British Alpine and Canindé are characterized by homogeneous genetic patterns each. The populations belonging to the different breeds were placed accordingly within each clade with high bootstrap support values for the nodes. 


\section{Table 6. Nei’s genetic distance between Canindé and British Alpine populations.}

\begin{tabular}{l|l|l|l|l|r|r}
\hline \multirow{2}{*}{ Breed } & Population & \multicolumn{2}{|c|}{ Canindé } & \multicolumn{2}{c}{ British Alpine } \\
\cline { 3 - 7 } & & UFC & ELV & EUS & QUI & JAG \\
\hline \multirow{3}{*}{ Canindé } & UECE & 0.289 & 0.578 & 0.971 & 0.101 & 0.151 \\
\cline { 2 - 7 } & UFC & & 0.372 & 1.147 & 1.154 & 1.469 \\
\cline { 2 - 7 } & ELV & & & 0.872 & 0.803 & 0.236 \\
\hline \multirow{2}{*}{ British Alpine } & EUS & & & & 0.522 & 0.249 \\
\cline { 2 - 7 } & QUI & & & & & \\
\hline
\end{tabular}
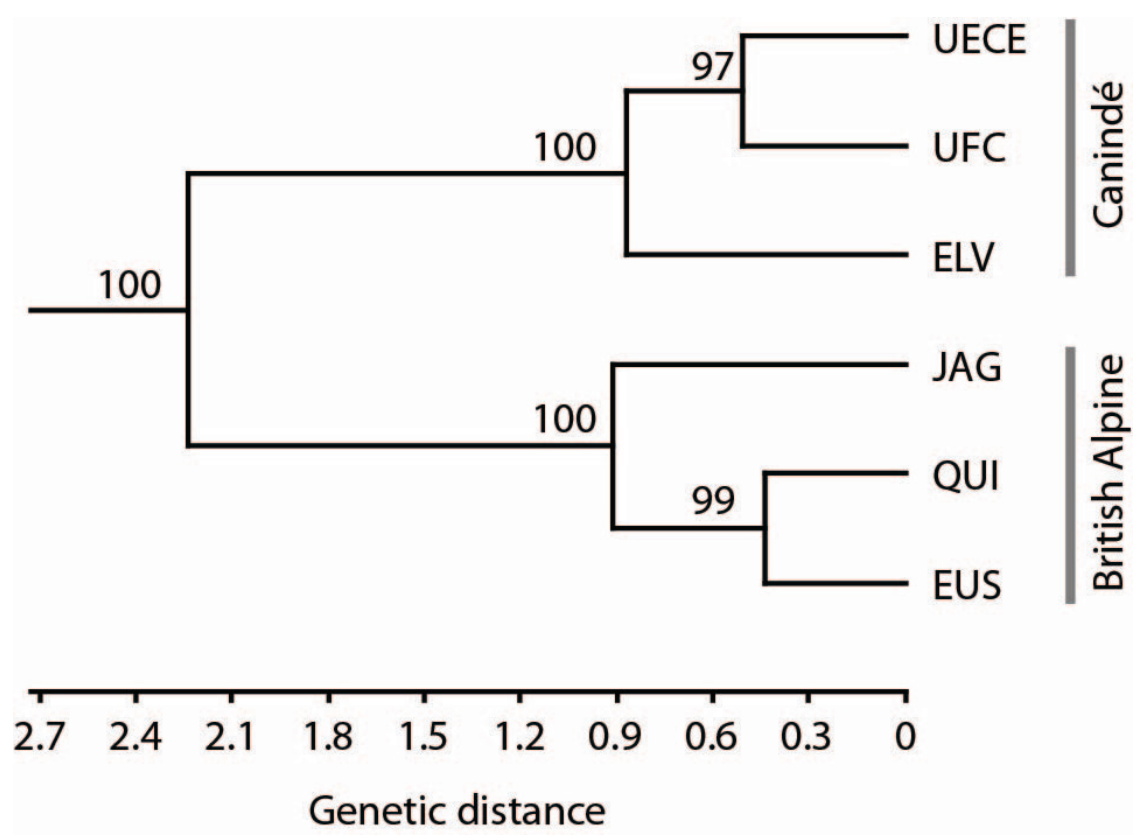

Figure 6. Unrooted UPGMA tree constructed from microsatellite loci for Canindé and British Alpine goat populations from Piauí and Ceará according to Nei (1972)'s genetic distance. Numbers represent the percentage of times that a node occurred in 1000 bootstrap replicates.

\section{DISCUSSION}

The conservation of flanking regions of microsatellite sequences between phylogenetically related species allowed the use of heterologous primers to amplify markers for estimating the genetic diversity and relatedness between the Canindé and British Alpine goat breeds. Cross-species transfer of microsatellite markers has been reported in several animal domestic species. For instance, Rocha et al. (2016) found a cross-amplification rate around $70 \%$ for sheep and cattle microsatellite markers in goats. In our study, $60 \%$ of all markers used to amplify goat microsatellites were from different Bovidae species, which also showed high-quality cross-amplification and polymorphism.

The overall mean number of alleles per locus for Canindé (5.9) and British Alpine (5.5) breeds obtained from genotyping was within the ISAG/FAO recommendations (FAO, 1993) to characterize genetic diversity, which is suggested to be at least four alleles per

Genetics and Molecular Research 16 (1): gmr16019569 
locus. According to Barker (1994), fewer alleles $(<4)$ could reduce the effect on standard error for genetic distance calculations between populations. Previous studies of indigenous Brazilian breeds showed large variation in numbers of alleles, with averages varying from 3.5 to 9.6 (Araújo et al., 2006; Menezes et al., 2006). For Britsh Alpine goats, mean number of microsatellite alleles was earlier found to be $6.84 \pm 2.08$ (Bosman et al., 2015).

Highly polymorphic microsatellite markers are critical for genetic variation analysis in conservation genetic studies, as the presence of multiple alleles within a locus is an indication of variation, which in turn ensures a set of representative data. A locus is considered highly polymorphic if its heterozygosity is greater than 0.70 (Ott, 1992). In this study, the majority (94.11\%) of microsatellite loci were highly polymorphic $\left(H_{\mathrm{O}} / H_{\mathrm{E}}>0.7\right)$ in the whole population composed by the pooled samples.

The mean observed heterozygosity estimation in this study for both Canindé and British Alpine (0.925 and 0.906, respectively) is higher than reported in Brazilian naturalized and exotic purebred domestic goats, from 0.320 to 0.460 (Oliveira et al., 2007), probably due to the fact that the choice for microsatellite markers was substantially different, which produced different results, and/or the presence of non-amplified alleles, as no test for the presence of nulls or scoring errors was performed in their study. Nevertheless, high $H_{\mathrm{O}}$ values (i.e., 0.880 $\left.<H_{\mathrm{O}}<0.980\right)$ are also reported in the literature for other goat breeds at different microsatellite loci (Araújo et al., 2006; Oliveira et al., 2010; Bulut et al., 2016). The mean values of observed and expected heterozygosities in the breeds analyzed were high ( $\geq 0.696$; Table 4$)$, suggesting a high genetic variability.

The differences between observed and expected heterozygosities, giving negative or close to $0, F_{\text {IT }}$ and $F_{\text {IS }}$ values are often explained by balancing selection at a locus, operating through overdominance, negative assortative mating, and/or as an asymmetrical sex migration that produced an outbreeding effect in the progeny (Parreira and Chikhi, 2015). As overdominance is usually locus-specific, it is unlikely to explain the excess of heterozygotes across most microsatellite loci in the present study. Most microsatellite loci, except CSRM60, INRA23, and HAUT27, contributed to the overall global excess of heterozygotes within pooled populations of the studied breeds. Therefore, the introduction of genotypes from other goat populations with divergent allele frequencies in male and female parents as a specific management system or translocation, with the intent to improve the productive indexes of the herds or, when is the case, to reduce inbreeding avoiding mates between closely related animals is a more likely explanation. Male and female breeder allele frequency differences in small randomly mating populations can also be due to binomial sampling error (Allendorf and Luikart, 2007). The negative values of mean $F_{\text {IS }}$ in British Alpine (-0.322) and Canindé $(-0.333)$ goats, supported by the high levels of average observed heterozygosity exhibited by both breeds, is an evidence that mating between less closely related individuals is common.

Most of the loci in this study were significantly deviated from HWE across all individuals (Table 3) and within studied goat breed (Table 4). In order for a population to be in HWE this population should be very large in size, with random mating or no preference for particular genotypes, and in the absence of migration of breeding individuals among populations, of mutation and natural selection (Hardy-Weinberg law). Consequently, both allele and genotype frequency will become constant from one generation to the next. Violations of HWE assumptions are likely to occur in molecular marker studies when it comes to domestic livestock breeds where artificial selection, via the process of breeding, is common. Breeding programs aimed to maximize genetic variability in the herd and the introduction of individuals

Genetics and Molecular Research 16 (1): gmr16019569 
belonging to other genetically close breeds for the reproduction might also play an important role in departures from HWE, as changes in heterozygosities would be detected over time.

HWE deviations have also been reported in other population genetic studies on goats (Menezes et al., 2006; Oliveira et al., 2007; Dixit et al., 2012).

Similarly, average PIC estimates for all pooled loci (0.757) and for each individual breed ( $>0.636)$ was high, indicating adequacy for analyzing genetic diversity within and between populations. This value was comparable with the PIC of the Brazilian Moxotó and the Portuguese Serpentina breeds (0.720; Oliveira et al., 2010). Menezes et al. (2006) also found PIC estimates of similar magnitude (0.635) for Moxotó, Canindé, Serrana Azul, Marota, Repartida, and Graúna breeds using 27 microsatellite loci.

Despite the criticism in that $F_{\mathrm{ST}}$ and $G_{\mathrm{ST}}$ statistics may underestimate differentiation at high levels of heterozygosity measured by microsatellite loci (Wang, 2015), these indices are still considered useful measures of genetic differentiation (Whitlock, 2011). In our study, $F_{\text {ST }}$ $(0.18)$ and $\mathrm{G}_{\mathrm{ST}}(0.10)$ imply a considerable degree of differentiation among goat populations (Table 3). $F_{\mathrm{ST}}$ values between 0.05 and 0.3 are typical of differentiated livestock breeds (Frankham et al., 2002).

Differences between goat breeds from Portugal (Serpentina) and Brazil (Moxotó) assessed by microsatellite markers (Oliveira et al., 2010) was estimated by an $F_{\mathrm{ST}}$ of 0.16 , which is comparable to the level of differentiation obtained in our study $\left(F_{\mathrm{ST}}\right.$ of 0.18$)$. These estimates, however, are higher than what has been reported between Alpine and Saanen dairy goats and the naturalized Brazilian Moxotó breed (Araújo et al., 2006), between Brazilian naturalized, exotic purebreds and crossbred goats (Oliveira et al., 2007), and between locally adapted Crespa goats and the phenotypically similar Angora breed (Lopes et al., 2016).

The genetic differentiation was further confirmed by AMOVA (Table 5), which revealed to be significant $(\mathrm{P}<0.05)$ among populations (without predefined groups) and between breed variation (with a hierarchical structure), and therefore, an evidence of genetic distinctness in the studied goat breeds. AMOVA on unstructured populations indicated that $18.4 \%$ of the total variation could be attributed to differences among populations (AMOVA $\left.F_{\mathrm{ST}}=0.184\right)$, which corroborates the $F_{\mathrm{ST}}$ value $(0.18)$ detected for all pooled populations (Table 3). When populations were grouped according to breeds, AMOVA attributed $12.8 \%$ of the total variation by differences between breeds and $10.2 \%$ among populations within breeds, once again, providing an additional clue for the assumed differentiation between British Alpine and Canindé. Among individuals within populations, variation was negative for the variance components and its corresponding percent variation because these estimates are rather covariances. Biologically this may occur, for instance, in outcrossing individuals, where a strong correlation can be observed between genes from different populations compared with genes from the same population (Schneider et al., 2000). A negative variance component for among individuals within populations indicated the absence of genetic structure within population suggesting single local populations. The high $\mathrm{P}$ value $(\mathrm{P}=1.0000)$ for this source of variation indicated non-statistically significant differences in the frequencies of the marker examined between the targeted populations. In addition, the negative within-population variance components may also reflect the heterozygote excess observed in all populations (Table 3), which can occur in small populations and following population bottleneck events (Falconer, 1989).

The differentiation observed between British Alpine and Canindé was also confirmed by Nei's unbiased genetic distance among populations (Table 6) and a well-supported tree

Genetics and Molecular Research 16 (1): gmr16019569 
topology on the basis of microsatellite genotyping with two clusters clearly defined for the two investigated breeds (Figure 6). This graphical representation of population distances highlights that British Alpine and Canindé goats are characterized by contrasting genetic patterns. Our results are in close agreement with findings from Ribeiro et al. (2012) who separated the Alpine goat outgroup from the Portuguese and Brazilian breeds.

The genotypic data also revealed that within Canindé goats the sites UECE and UFC are the closest populations. Similarly, for British Alpine breed, the populations from QUI and EUS have the smallest genetic distance for all of the comparisons. This within-breed scenario of population distribution may be influenced by the trade of animals among farms/populations useful for breeding, which in turn, is facilitated by the geographical distance from nearest neighbor populations (Figure 2). The manipulation of herds by farm owners can result in distinct distribution patterns of these populations. A clear distinction was observed between herds from UECE and ELV for Canindé and from EUS and JAG for British Alpine, probably due to the fact that these populations are in rapid process of genetic dilution caused by directed matings inducing future genetic isolation with the purpose of increasing the production rates of livestock (Ribeiro et al., 2004). It is valid to mention that differences in management conditions and geographic peculiarities may gradually lead to genetic differentiation, and in Northeast Brazil, management of herds are rather different and opportunity for admixing is less frequent (Oliveira et al., 2010). Another fact that should be also added into this discussion is the local existence of a crossbreed goat commonly called Canindé that is not the same as the naturalized Canindé (Lôbo et al., 2010) sampled in this study.

As the effects of admixing may be overlooked in the reconstruction of phylogenetic relationships between breeds, we further assessed the genetic differentiation between British Alpine and Canindé goats with a Bayesian analysis of a classical admixture model (Figure 4) and a principal component analysis (Figure 5). The Bayesian STRUCTURE clustering detected the maximum likelihood for a model of two genetically distinct groups $(K=2)$, in agreement with the number of predefined studied breeds. This result reflects what we found with the two-dimensional plot from the PCoA analysis in which the different individuals were assigned to a graphical representation. The two breeds were clearly differentiated by the first two coordinates, which illustrates the distinctness of the breeds. These analyses, once again were consistent with the results obtained with the pattern of UPGMA clustering for each population within breeds, confirming the expected relationship among populations from same breed (Figure 6). The observed congruence among the results from different strategies for studying the genetic differentiation between Canindé and British Alpine goats highlights the robustness of these results. Even though some degree of crossbreeding would be expected between these two phenotypically similar breeds, the idea of two evolutionary lineages is reinforced by these microsatellite data.

In summary, our results further support cross-species transferring of nuclear microsatellite markers in inferring the degree of divergence and genetic relationships of goat breeds, and therefore, could be useful for future breeding and conservation programs with the studied breeds. The microsatellite data revealed that genetic diversity is high and great variability exists within individuals across populations. Additionally, the imported British Alpine and the naturalized Brazilian Canindé have distant genetic identities, in spite of the great phenotypic similarity. These conclusions were supported by individual (STRUCTURE analysis, PCoA), and population level ( $F_{\mathrm{ST}}$ and $G_{\mathrm{ST}}$ statistics, AMOVA, Nei's $D$ value, UPGMA distance tree) analyses. Further studies, however, with additional molecular markers

Genetics and Molecular Research 16 (1): gmr16019569 
of mitochondrial origin, as well as continued sampling of additional populations would help understanding the distribution and origin of present-day genetic diversity and demographic history of these breeds.

\section{Conflicts of interest}

The authors declare no conflict of interest.

\section{ACKNOWLEDGMENTS}

Coordenação de Aperfeiçoamento de Pessoal de Nível Superior (CAPES) granted a scholarship to T.S. Câmara. The authors also wish to thank Universidade Federal do Piauí for the support and rural owners who provided biological samples used in this study. Research supported by EMBRAPA (Código SEG: 01.06.01.006.05.08).

\section{REFERENCES}

Allendorf FW and Luikart G (2007). Conservation and the genetics of populations. Blackwell, Malden.

Araújo AM, Guimarães SEF, Machado TMM, Lopes PS, et al. (2006). Genetic diversity between herds of Alpine and Saanen dairy goats and naturalized Brazilian Moxotó breed. Genet. Mol. Biol. 29: 67-74. http://dx.doi.org/10.1590/ $\underline{\mathrm{S} 1415-47572006000100014}$

Barker JSF (1994). A global protocol for determining genetic distances among domestic livestock breeds. In: World Congress on Genetics Applied to Livestock Production. Guelph.

Bosman L, Van Marle-Köster E and Visser C (2015). Genetic diversity of South African dairy goats for genetic management and improvement. Small Rumin. Res. 123: 224-231. http://dx.doi.org/10.1016/j.smallrumres.2014.12.003

Bulut Z, Kurar E, Ozsensoy Y, Altunok V, et al. (2016). Genetic Diversity of Eight Domestic Goat Populations Raised in Turkey. BioMed Res. Int. 7: 1-6. http://dx.doi.org/10.1155/2016/2830394

Dixit SP, Verma NK, Aggarwal RAK, Vyas MK, et al. (2012). Genetic diversity and relationship among Indian goat breeds based on microsatellite markers. Small Rumin. Res. 105: 38-45. http://dx.doi.org/10.1016/j.smallrumres.2011.11.026

Earl DA and VonHoldt BM (2012). STRUCTURE HARVESTER: a website and program for visualizing STRUCTURE output and implementing the Evanno method. Conserv. Genet. Resour. 4: 359-361. http://dx.doi.org/10.1007/s12686$\underline{011-9548-7}$

Evanno G, Regnaut S and Goudet J (2005). Detecting the number of clusters of individuals using the software structure: a simulation study. Mol. Ecol. 14: 2611-2620. http://dx.doi.org/10.1111/j.1365-294X.2005.02553.x

Falconer D (1989). Introduction to quantitative genetics. 3rd edn. Longman Scientific \& Technical with Wiley \& Sons Inc., New York.

FAO (Agriculture Series) (1993). Food and agriculture organization of the United Nations. FAO, Rome.

Frankham R, Ballou JD and Briscoe DA (2002). An Introduction to Conservation Genetics. Cambridge University Press, Cambridge.

Goudet J (2002). FSTAT: a program to estimate and test gene diversities and fixation indices (version 2.9.3.2). University of Lausanne, Department of Ecology \& Evolution, Lausanne.

Hammer O, Harper DAT and Ryan PD (2001). PAST: Paleontological Statistic software package for education and data analysis. Paleont. Eletron. 4: 1-9.

IBGE (2012). Pesquisa Nacional por Amostra de Domicílios - PNAD de 2012. Ministério do Planejamento e Orçamento, Rio de Janeiro.

Jakobsson M and Rosenberg NA (2007). CLUMPP: a cluster matching and permutation program for dealing with label switching and multimodality in analysis of population structure. Bioinformatics 23: 1801-1806. http://dx.doi. org/10.1093/bioinformatics/btm233

Lôbo RNB, Facó O, Lôbo AMBO and Villela LCV (2010). Brazilian goat breeding programs. Small Rumin. Res. 89: 149154. http://dx.doi.org/10.1016/j.smallrumres.2009.12.038

Lopes DD, Fernández GP, Poli M, Moreira GRP, et al. (2016). Ancestry analysis of locally adapted Crespa goats from southernmost Brazil. Genet. Mol. Res. 15: http://dx.doi.org/10.4238/gmr.15028324.

Genetics and Molecular Research 16 (1): gmr16019569 
Marshall TC, Slate J, Kruuk L and Pemberton JM (1998). Statistical confidence for likelihood-based paternity inference in natural populations. Mol. Ecol. 7: 639-655. http://dx.doi.org/10.1046/j.1365-294x.1998.00374.x

$<$ unknown>McManus C, Paiva S and Louvandini H (2010). INCT: Informação Genético-Sanitária da pecuária Brasileira. Série técnica: Genética. Caprinos no Brasil. </unknown>

Menezes MPC, Martinez AM, Ribeiro MN, Filho EC, et al. (2006). Caracterização genética de raças caprinas nativas brasileiras utilizando-se 27 marcadores de microssatélite. Rev. Bras. Zootec. 35: 1336-1341. http://dx.doi.org/10.1590/ $\underline{\mathrm{S} 1516-35982006000500012}$

Nei M (1972). Genetic distance between populations. Am. Nat. 106: 283-291. http://dx.doi.org/10.1086/282771

Nei M (1973). Analysis of gene diversity in subdivided populations. Proc. Natl. Acad. Sci. USA 70: 3321-3323. http:// dx.doi.org/10.1073/pnas.70.12.3321

Noah AR (2004). Distruct: a program for the graphical display of population structure. Mol. Ecol. Notes 4: 137-138.

Nunes JF, Ciríaco ALT and Suassuna U (1997). Produção e Reprodução de caprinos e ovinos. 2nd edn. Ed. LCR, Fortaleza.

Oliveira JCV, Ribeiro MN, Rocha LL, Gomes-Filho MA, et al. (2010). Genetic relationships between two homologous goat breeds from Portugal and Brazil assessed by microsatellite markers. Small Rumin. Res. 93: 79-87. http://dx.doi. org/10.1016/j.smallrumres.2010.05.002

Oliveira JD, Igarashi MLSP, Machado TMMM, Miretti MM, et al. (2007). Structure and genetic relationships between Brazilian naturalized and exotic purebred goat domestic goat (Capra hircus) breeds based on microsatellites. Genet. Mol. Biol. 30: 356-363. http://dx.doi.org/10.1590/S1415-47572007000300010

Ott J (1992). Strategies for characterizing highly polymorphic markers in human gene mapping. Am. J. Hum. Genet. 51: 283-290.

Parreira B and Chikhi L (2015). On some genetic consequences of social structure, mating systems, dispersal, and sampling. Proc. Natl. Acad. Sci. USA 112: 3318-3326. http://dx.doi.org/10.1073/pnas.1414463112

Peakall R and Smouse PE (2012). GenAlEx 6.5: genetic analysis in Excel. Population genetic software for teaching and research - an update. Bioinformatics 28: 2537-2539. http://dx.doi.org/10.1093/bioinformatics/bts460

Pritchard JK, Stephens M and Donnelly P (2000). Inference of population structure using multilocus genotype data. Genetics 155: 945-959.

Raymond M and Rousset F (1995). GENEPOP (version 1.2): population genetics software for exact tests and ecumenicism. J. Hered. 86: 248-249. http://dx.doi.org/10.1093/oxfordjournals.jhered.a111573

Ribeiro MN, Oliveira JCV, Rocha LL, Alves AGC, et al. (2004). Caracterización, evaluación y conservación de caprinos Moxotó en el Estado de Pernambuco, Brasil. Arch. Latinoam. Prod. Anim 12: 54-58.

Ribeiro MN, Bruno-de-Sousa C, Martinez-Martinez A, Ginja C, et al. (2012). Drift across the Atlantic: genetic differentiation and population structure in Brazilian and Portuguese native goat breeds. J. Anim. Breed. Genet. 129: 79-87. http://dx.doi.org/10.1111/j.1439-0388.2011.00942.x

Rocha LL, Filho ECP, Filho MAG, Delgado JV, et al. (2016). Impact of foreign goat breeds on the genetic structure of Brazilian indigenous goats and consequences to intra-breed genetic diversity. Small Rumin. Res. 134: 28-33. http:// dx.doi.org/10.1016/j.smallrumres.2015.12.002

Santos R (2003). A cabra e a ovelha no Brasil. Editora Agropecuária Tropical. Uberaba.

Schneider S, Roessli D and Excoffier L (2000). Arlequin: A software for population genetics data analysis. Available at [http://lgb.unige.ch/arlequin/]. Ver 2.000. Genetics and Biometry Lab, Dept. of Anthropology, University of Geneva, Geneva.

Truett GE, Heeger P, Mynatt RL, Truett AA, et al. (2000). Preparation of PCR quality mouse genomic DNA with hot sodium hydroxide and Tris (HotSHOT). Biotechniques 29: 52-54.

Van Oosterhout C, Hutchinson WF, Wills DPM and Shipley PF (2004). MICRO-CHECKER: For identifying and correcting genotyping errors in microsatellite data. Mol. Ecol. Notes 4: 535-538. http://dx.doi.org/10.1111/j.1471$\underline{8286.2004 .00684 . x}$

Wang J (2015). Does GST underestimate genetic differentiation from marker data. Mol. Ecol. 24: 3546-3558. http://dx.doi. org $/ 10.1111 / \mathrm{mec} .13204$

Whitlock MC (2011). $G_{\mathrm{ST}}$ and $D$ do not replace $F_{\mathrm{ST}^{*}}$ Mol. Ecol. 20: 1083-1091. http://dx.doi.org/10.1111/j.1365294X.2010.04996.X

Genetics and Molecular Research 16 (1): gmr16019569 